\title{
結核免疫ノ研究 (第一報)
}

\section{結核罹患海璂體內二於ケル結核菌發育阻止物質ノ產生涉ビ二 其ノ消長二就テ(人型菌 $\mathrm{H}_{2}$ 株キ用七テノ實驗)}

（昭和 16 年 6 月 21 日受付）

傳染病研究所第一研究部(部長 細谷省望钽授)

$\begin{array}{lll}\text { 桑 } & \text { 島 } & \text { 謙 } \\ \text { 村 } \\ \end{array}$

（本研究八䠶二第 15 回聯合微生物學會及ビ昭和 16 年 6 月 19 日傳染病研究所學術集談會二於テ表表シタ）

\section{粕 言 \\ 實 驗}

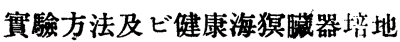
結核臛患海㩧, 䑏器培地

結核菌人型 $\mathrm{H}_{2} 1 / 10 \mathrm{mg}$ 习海䐎皮下二接種シタ 場合

結核菌人型 $\mathrm{H}_{2} 1 / 1.000 \mathrm{mg} 9$ 海猽皮下二接種
目次

夕埸合

BCG $\ni$ 海㩧皮下二接種シタ場合 結核自然感染牛, 肝矐培地 結核菌發育阻止物資，作用檢討

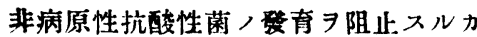

人型菌 $\mathrm{H}_{2}$ 二隇殺的二作用スルカ 考察站ビ二結論

\section{緹䨐}

結核ノ解疫チ云々スル二當り，他人細菌ト著ルシク異ナル點トシテ結核菌ノ被膜キ無視久ルコト 八出來ナイ。此ノ特有ナル菌體ノ構造き基礎トシテ結核ノ全テガ論ゼラレル可キデァルト考へル。

結核菌二對 シ感受性アル動物ガ結核菌ノ再感染二抵抗スル事が. Koch (1)，基礎賽驗ニョリ賽驗的 端緒キ開イテ以來. 現代八結核免疫，理論／確立キ見タガ. 此，再感染へ八抗抗八單二Allergie， そデハ說明シ得ラレナイトサレテ居ル。郎于實驗的ニハ一定ノ條件下二ハAllergie，ナイ免度(抵 抗）ガ成立スル事が又八其，反對二免疫ナシニAllergie，i存入ルコトガ. 多ク，學者二依り立證 サレテ居ルカラデアル。而シテヌ此ノ再感染へ，抵抗ナル現像八緗胞，活動ト云フガ如キ抽象的言 鲛キ以テシテハ何人・モ首肯シ得ナイ。結核ノ免疫八恐ラク複雜多岐二互ル要素二關聯スルノデァラ ウガ. 上述ノ如キ結核菌々體ノ特有ナル構造き根據二置イテ考察スルト. 結核菌ハ生體內二於テ容 易二死隇セヌノデアルカラ.結核動物へ，再感染二對スル抵抗ガ真，意味二於ケル結核，免疫デァ

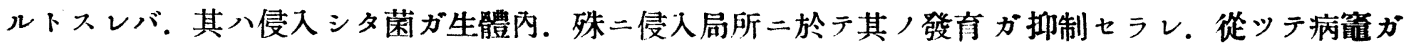
新生セラレ難クナルト云フ事ガ根本デナケレバナラヌト考へラレル。而シテ此ノ抑制八細胞ト菌卜 
ノ閉爭ノ結果. 生體細胞カラ菌二向ツテ分泌セラレルカ. 或ハ單二細菌ニョリ變性サレタ組樴細胞 ノ成分トシテ形成サレルカ. 孰レデアルニシテモ。鬼二角生體內二產生サレル發有阻止物質卜云フ 具體的ノ事實デアルト考へタイ。斯ノ如ク侵入局所或ハ侵入蔵器二發有阻止物質ガアッテ. 是ニョ リ抵抗が成立スルトスレバ. 其八所謂組織免疫デアルト考へタクナル。

生體內二斯ノ如キ結核菌發育阻止物質ガ産生セラレルトシテモ. 如何ニシテ之タ證明スルカノ手 段カ問題トナツテ來ル。

偶々. 日置氏 ${ }^{(2)}$ 二依ルト肺結核患者喀痰中二八耐热性ノ結核菌發育阻止物質が存在スルト云フ事

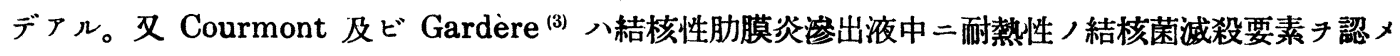
テ居ル。私ハ之レ等, 研究二示唆サレ. 若シモ結核䍜患海猽體內二形成サレタ結核菌發育阻止物質 ガ酎熱性デアルト假定スレバ. 培養基, 調製, 上カラ見テモ. 又研究室感染,危險カラモ. 極メテ 安全二且ツ又容易迅速二此ノ物質, 證明ガナシ得ルト考へ. 細菌免疫ノ理論及ビ實際上豐富ナル經

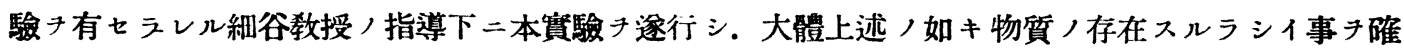
認スル二至ツタノデ. 未完成デハアルガ此處二報告シ. 御先輩諸先生方ノ御批制テ乞フ者デァル。 少本研究二八病理組織學的研索ガ缺ケテ居ルガ.ソノ研究八今後二绕ル事キ諒トセラレタイ。

\section{赛 酸}

\section{定駩方法及ビ健廉海猽䑏器剒地}

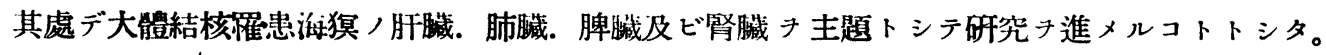
之二入ルニ先立ッテ健康海獏二就テ以上四藏器ナ主トシ. 其ノ他種々ナル臟器二就テ 20 數回ノ實 驗丹繰り返へシタ。

「エーテル」テ以ッテ府醉死セシメタ體重 $350 \mathrm{gr}$ 以上ノ健康雄海獏數正二就テ．新鮮ナル各臟器き 三角「コルベン」ニ入レ綿栓後. $100^{\circ} \mathrm{C}=1$ 時間加熱スルト各葴器ハ比較的脆クナッテ碎キ易クナリ. 罹患海猽ノ場合二八結核菌キ殺菌シタ事ニナル。此ノ隇菌シタ矌器 1 二對シ 2 ノ割合デ蒸䬯水キ加

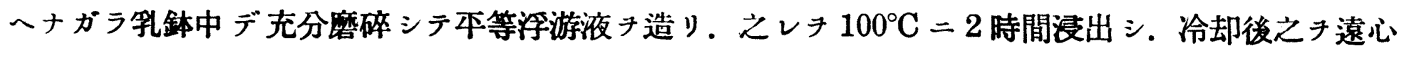
シテ. 其ノ遠心上清二蒸餾水年加へテ原量二復シ. 之二 Glycerin $4 \%$. Pepton $1 \%$. 食監 $0.5 \%$ . 寒天 $33 \%$, 割二加へ. 加熱溶解後 $\mathrm{pH} \neq 7$ 二修正シ. 其, 8-10c. 試驗管 二分注後. $100^{\circ} \mathrm{C}$ 30 分 3 回ノ隇菌施シテ後. 斜面 Glycerin 寒天トシテ使用ニ供シタノデァル。

之八培養基二人型菌 $\mathrm{H}_{2}$ (强毒菌)，Glycerinbouillon 3 週日培養濃厚本等浮游液 (生理的食監水)

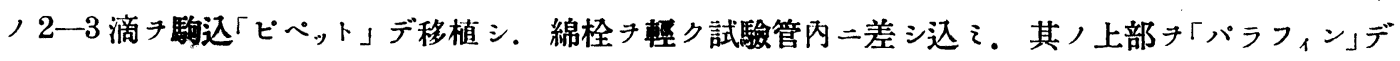
密封シ。培地, 乾燥キ防ギッッ $37^{\circ} \mathrm{C}=30$ 日間培養キ續ヶタ。此ノ際最モ注意入可キ事八培養菌, 本等浮游夜製作二當り。光分瑪㻦, 孚錸中デ結核菌キ念入リ二研磨シテ粗大ノ菌塊き殘サナイコト デアル。若シ大キナ菌塊テ培地上二落スト多少ノ發育阻止作用ハ無視シテ發育スル傾向がアル。更 二凝結水乾煰セシメナイ事が大切デアル。 
上上, 如クニシテ健康海猽, 各臟器培地二結核菌人型 $\mathrm{H}_{2}$ 于植エ $37^{\circ} \mathrm{C}=30$ 日間放置 久ルト, 其

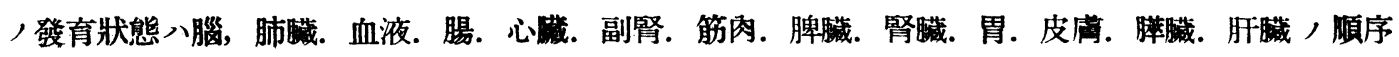
デ. 殊二腦. 肺. 血液. 腸二於ヶル發育八極メテ顯著デアリ.心陚。副腎. 笳肉二於テ八良好. 脾. 腎. 胃. 皮膚. 膵デハ菌ノ發育普通二八䡴微. 肝二至ツテハ其，發育八極メテ不良デアル。從ッテ 肝培地二於テ八原液 (2 倍). 3 倍. 4 倍. 5 倍. 10 倍等八稀释き製シテ其八阻怍用チ檢シタ。健康海 猽肝培地, 結核菌發育阻止作用八多ク原液二於テノミ見ラレタノデアルガ. 時二八甚シク其，矩育 キ阻止スル場合ガアリ。詳細二檢查シテ其ノ1群ノ海猽中カラ $100 \%=$ Bacillus bronchisepticus チ證明シタ事モアッタガ. 又全ク不明ノ事モ多々アッタ。斯ノ如キ一般二朋培地，發育不良ナ八 八 今村氏. 米田氏 ${ }^{(4)}$ 等, 見ル如キ Bilurbin /影票デァルカモ知レヌ。然シ健康, 肺. 脾. 腎八程度, 差コソアレ常二結核菌ノ發育キ認メタノデァル。

\section{結核䍜患海猽ノ臓器培地}

\section{結核菌人型 $\mathrm{H}_{2} \quad 1 / 10 \mathrm{mg}$ ᄏ海溟皮下二接種シタ堨合}

結核菌人型 $\mathrm{H}_{2}$ ， Glycerinbouillon 3 週日培養于雄健康海猽，鼠蹊部皮下二卅等浮游液（生理的 食監水)トナシ. 其, $1 / 10 \mathrm{mg}$ チ接種シテ. 每週 2 正宛「エーテル」デ殺シ. 其ノ肺. 脾. 肺. 腎, 四臟器培地チ製シ。殊二肝デ八原液 ( 2 倍)。3 倍. 4 倍. 5 倍等，培地キ作り。シ二.人型菌 $\mathrm{H}_{2}$ Glycerinbouillon，濃厚本等浮游液キ移植シタコトハ前述シタ健康游猽培地，場合卜全ク同樣デア ル。

解剖所見丹見ルト第 1 週ノ終リデハ局所ノ淋巴腺ハ米粒大トナルノミデアルガ. 第 2 週二八鼠躁 腺ガ同樣ナ肥大き呈シテ來ル。第 3 週二至ルト殆ンド全テノ淋巴腺八米粒一針頭大二達スルト共二.

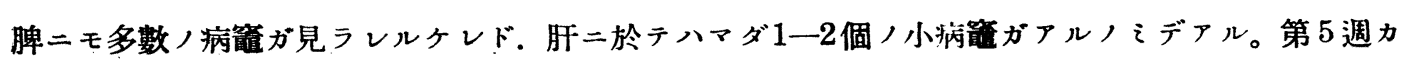

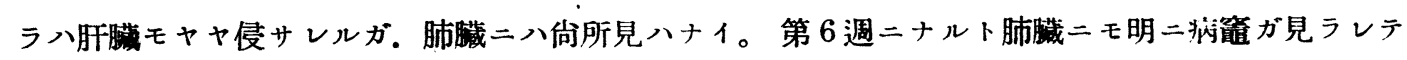
來ル。Tuberkulin 反應八第 1 週ノ終リカラ既二陽性デァル。

培養所見カラ見ルト(第 1 表)。著ルシイ事ハTuberkulin 反應が陽性トナツタ第 1 䓢直後二八.

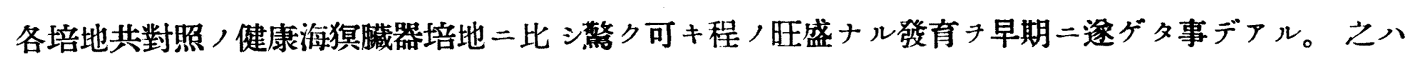
後二詳細二報告スル事、スル。第 2 週二於テ八肝培地. 脾培地八共二結核菌, 發育チ阻止スルガ.

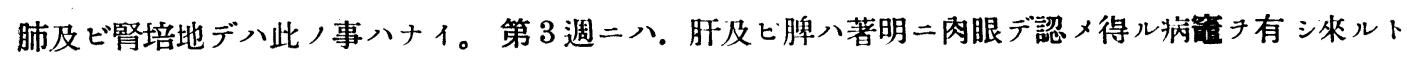
共二此ノ作用八兩培地共消失スル。斯ノ如ク肉眼デ見得ル病韽, 形成七ラレル約 1 週間位前二阻止

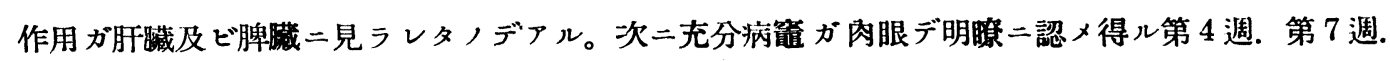
第 10 週二於テモ肝培地八脾培地ト件ツテ同時二結核菌, 發育き阻止スル。斯ノ如ク一進一退スル現 像力゙賽驗結核二特有ナノデアラウカ。勿論 1 正ノ海猽二就テ持續的二覞察シタノデハナイカラ.動 物, 個性差二依り斯ノ如キ結果チ招來セシメタノデァルカモ知レナイ。ヌ Bacillus bronchisepticus 
第 1 表人型菌 $\mathrm{H}_{2} 1 / 10 \mathrm{mg}$ 接種海猉各哭器培地二於々ル結核菌ノ培養

(培養モ $\mathrm{H}_{2}$ ヨ以テシ $37^{\circ} \mathrm{C} 30$ 日ノ結果デアル)

\begin{tabular}{|c|c|c|c|c|c|c|c|c|c|}
\hline 睵 器 培 地 & \multicolumn{6}{|c|}{ 胙 } & 脾 & 肺 & 腎 \\
\hline 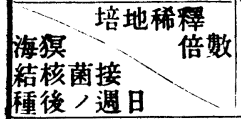 & $2 \times$ & $3 \times$ & $4 \times$ & $5 \times$ & $6 \times$ & $10 \times$ & $2 \times$ & $2 \times$ & $2 \times$ \\
\hline 1 & 册 & 删 & 册 & 册 & 册 & 册 & HI & 曲 & m \\
\hline$\overline{2}$ & - & - & - & $+t$ & $H$ & $\mathrm{HI}$ & - & $\mathrm{H}$ & $\mathrm{HH}$ \\
\hline 3 & - & + & + & tt & $H$ & $\mathrm{HH}$ & $+t$ & $\mathrm{H}$ & H \\
\hline 4 & - & - & - & - & - & - & - & 册 & H \\
\hline 5 & - & tt & 册 & H & 册 & 册 & tt & $\mathrm{H}$ & 世 \\
\hline 6 & - & $t+$ & $\mathrm{HH}$ & $\mathrm{HH}$ & 册 & HI & $\mathrm{HH}$ & $\mathrm{H}$ & + \\
\hline 7 & 一 & - & - & - & - & - & - & $\mathrm{H}$ & $\mathrm{H}$ \\
\hline 8 & - & $+t$ & tt & tt & $\mathrm{HH}$ & 曲 & + & $\mathrm{H}$ & - \\
\hline 9 & - & - & t+ & $\mathrm{H}$ & $\mathrm{HH}$ & $\mathrm{HH}$ & tt & $t+$ & H \\
\hline 10 & - & - & - & $t+$ & $\mathrm{HH}$ & $\mathrm{HH}$ & - & $t+$ & HI \\
\hline 健 康 海 猽 & - & + & + & $t+$ & $\mathrm{H}$ & $\mathrm{HI}$ & H & $\mathrm{HH}$ & $\mathrm{H}$ \\
\hline
\end{tabular}

一 八發育セズ + 聚落 $1-2$ 個 ++ 聚落 10 個內外 $\mathrm{H}$ 聚落多數 册極メテ旺盛

ニヨル海猽間，自然感染二於テモ肝培地二結核菌へ，發育阻止作用ガ存スル點カラ見テ. 此, 阻止 作用八單二朋臟機能が一般的二非特異的二立進シタ事二起因スルノデアルカ全ク制斷二困シム所デ $ア ル 。$ 然シ此, 結核罹患海猽,肝卜脾培地ガ同時二結核菌へノ發有阻止作用チ呈シタノハ $\mathrm{H}_{2} 1 / 10 \mathrm{mg}$ 接種シタ場合特有デアッテ. Bacillus bronchisepticus /病變, 時モソノ他不明ノ原因デ. 肝培地 ニノi阻止作用チ見タ時卜ハ著ルシク其ノ所見チ異ニスル所デアル。

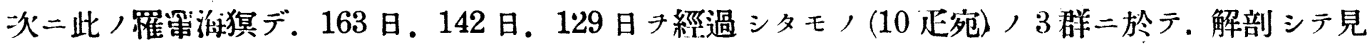
ルト．各群二於テ肝㖑，病變ガ比較的輕微デシカモ治瘾 シタ如キ感チ與へルモ（肝 I). 肝全部が 著ルシク肥大シ重クナツタモ（朋II). 更二此ノ陳舊ノ病變二新鮮ナル病筃ノ加ツタモノチ區別ス

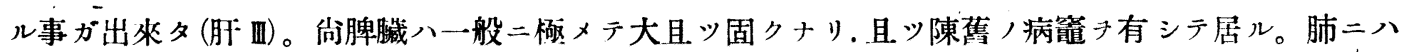
新鮮ナル病篧ガ多數二認メラレル。

第 2 表 人型菌 $\mathrm{H}_{2} 1 / 10 \mathrm{mg}$ 接種海谋(100 日以上)肝培地二於ヶル結核菌ノ培養 (人型菌 $\mathrm{H}_{2}, 37^{\circ} \mathrm{C} 30$ 日培養)

\begin{tabular}{|c|c|c|c|c|c|c|c|}
\hline $\begin{array}{l}\text { 海晖榷患 } \\
\text { 數 }\end{array}$ & $\begin{array}{r}\text { 培地稀程 } \\
\text { 肝䑏病露 }\end{array}$ & $2 \times$ & $3 \times$ & $4 \times$ & $5 \times$ & $6 \times$ & $10 \times$ \\
\hline \multirow{3}{*}{163 日 } & 腇 $\mathrm{I}$ & + & $\mathrm{HH}$ & 册 & 册 & m & 册 \\
\hline & 訮 II & + & H & 世 & iH & $\mathrm{HH}$ & 册 \\
\hline & 胡 III & - & + & + & $\mathrm{HH}$ & $\mathrm{HH}$ & $\mathrm{HH}$ \\
\hline \multirow{3}{*}{142 日 } & 訮 I & + & $\mathrm{HH}$ & $\mathrm{HH}$ & $\mathrm{HH}$ & $\mathrm{HH}$ & 册 \\
\hline & 訮 II & + & + & $t+$ & $\mathrm{H}$ & $\mathrm{HH}$ & mH \\
\hline & 訮 III & + & + & H & H & $\mathrm{H}$ & $\mathrm{HH}$ \\
\hline 129 日 & 訮 $I$ & + & Ht & H & tt & $\mathrm{HH}$ & 册 \\
\hline 健康海猽 & 訮 & + & $+t$ & H & $\mathrm{HI}$ & H & HII \\
\hline
\end{tabular}

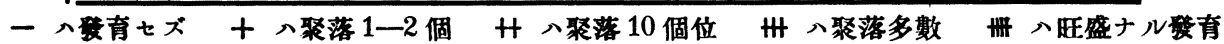


第 3 表 人型菌 $\mathrm{H}_{2} 3 / 10 \mathrm{mg}$ 接種海猽(100 日以上)肺.脾. 腎境地二於ヶル結核菌 發青 $\left(\mathrm{H}_{2}, 37^{\circ} \mathrm{C} 21\right.$ 日培善 $)$

\begin{tabular}{|c|c|c|c|c|c|c|c|c|c|}
\hline 培地 & & 肺 & & & 脾 & & & 霄 & \\
\hline 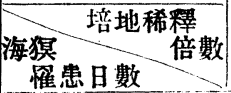 & $2 \times$ & $3 \times$ & $4 \times$ & $2 \times$ & $3 \times$ & $4 \times$ & $2 \times$ & $3 \times$ & $4 \times$ \\
\hline 163 日 & - & - & - & + & $H$ & $t+$ & $+t$ & tt & $H$ \\
\hline 142 日 & - & - & + & H & H & $\mathrm{Ht}$ & - & tt & $\mathrm{HH}$ \\
\hline 129 日 & - & - & $\mathrm{H}$ & + & + & + & + & + & H \\
\hline 健 㫤 海 猽 & + & $t+$ & $\mathrm{H}$ & $t+$ & $\mathrm{HH}$ & $\mathrm{HH}$ & $t$ & $\mathrm{HH}$ & $\mathrm{HH}$ \\
\hline
\end{tabular}

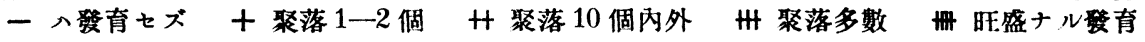

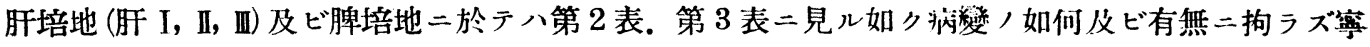
口結核菌ノ發育ハ助長七ラレテ居ル傾向ガアル。腎培地二於テモ結核罹患後 142 日, 10 正, 海猽二 アッテハ多少ノ阻止作用八認メラレルガ大シタ事ハナイ。仪之. 肺培地二於テハ䍜患日數ハ 163 日.

142 日. 129 日ト可成リ異ナルガ著明二結核菌ノ發育チ阻止スルノデアル。郎于人型菌 $\mathrm{H}_{2}$ チ活猽二 接種シテ 100 日以上日數テ經タ場合ニハ. 肺二於ヶル阻止作用ハ一進一退七ズ比較的其ノ作用八恒 在性デアッタワケデアル。此ノ事ハ健康海猽デハ全ク認メ得ナカッタ事實デアル。

\section{結核菌人型 $\mathrm{H}_{2} 1 / 1 \cdot 000 \mathrm{mg}$ 习海猽皮下二接程シタ場合}

次二微量 $(1 / 1.000 \mathrm{mg})$ 人型菌 $\mathrm{H}_{2}$ ， Glycerinbouillon 3 週日培養キ谁猽皮下二接種シタ場合二ハ。 上述ノ $1 / 10 \mathrm{mg}$ 接種ノ場合ト著ルシク其ノ趣キ異ニシテ來ル。

即于解剖所見カラ見ルモ第 3 週マデハ局所及ビ腸間膜ノ淋巴腺ガ 米粒大乃至針頭大二過ギナク. 脾藏及ビ肝臟二肉眼的二認メ得ル病瓷ノ生ズルハ第 5 週ノ終リカラデァル。而シテ Tuberkulin 反 應ハ未ダ內臟 (脾. 肝)二病筐ノ見ラレナイ第 3 週ノ終リ二發現スル。而シテ第 12 週マデノ觀察二於

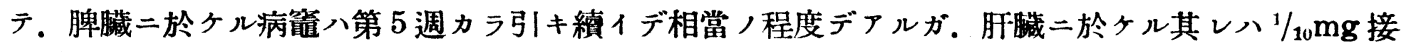
種二比シ遙二輕微デアル。罹患海猽ハ一般二見テ $1 / 10 \mathrm{mg}$ 接種時ヨリモ元氣旺盛デァルガ. 殊二第 8 週以後ハ其ノ體重キ增加シ又外觀的二モ非常二元氣チ增シタ如ク見へタ。

培盖所見八第 4 表二示ス如ク. Tuberkulin 反鷹陽性轉化時 タル第 3 遠二於テハ. 各臟器共著ル シク結核菌ノ發育が旺盛デアッタ事ハ1/10 mg 接種後 Tuberkulin 陽轉時ト全ク同樣デアル。但シ此 ノ場合二ハ脾培地デハ寧口結核菌ノ發育チ阻止シテ居ル。肝培地二於ケル結核菌發育阻止作用八第 9 週ノ終リ二至ルモ全然認メル事ハ出來ナク. 此ノ點 $1 / 10 \mathrm{mg}$ 接種ノ場合二見タ如キ感染早期ノ阻止 作用トハ異ナリ可成リ僬クナッテノ阻止作用ト云ハネバナラヌ。而シテ郎チ第 10 週二至ルト始メテ 肝培地二著明ナ阻止作用ガ發現シ來ルガ.此ノ時使用シタ淮猽 2 正ノ肝䯈二於ケル所見デハ.肉眼的

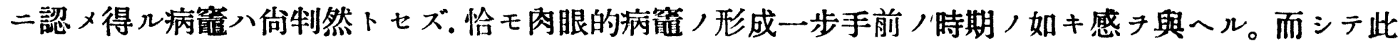
ノ肝培地ノ結核菌發有阻止作用八第 10 週以後第 12 週ノ終リ二至ルマデ多少ノ高低ハアルガ持續七 ラレル。即チ $1 / 10 \mathrm{mg}$ 接種時二見タ如キ. 其ノ阻止作用八比較的短日時デ消螁スル事實ト對比シ. 其 ノ作用ハ恒在性デァッタト云ハネバナラヌ。脾臟二於テハ肉眼的二見得ル病筑会ノ生ズル以前郎チ第 


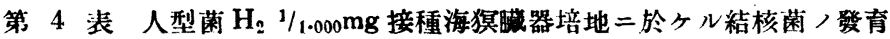
$\left(\mathrm{H}_{2}, 37^{\circ} \mathrm{C} 30\right.$ 日培養 $)$

\begin{tabular}{|c|c|c|c|c|c|c|c|c|}
\hline 甈 器 培 地 & & & 肝 & & & 脾 & 肺 & 腎 \\
\hline 海掼患週日 倍数 & $2 \times$ & $3 \times$ & $4 \times$ & $5 \times$ & $10 \times$ & $2 \times$ & $2 \times$ & $2 \times$ \\
\hline 2 &. & H & H & H & $\mathrm{HH}$ & + & H & H \\
\hline 3 & $\mathrm{HH}$ & HI & 曲 & 曲 & 册 & - & HI & 世 \\
\hline 5 & - & H & 册 & 册 & 册 & W & 册 & H \\
\hline 6 & - & + & + & H & H & tt & H & $\mathrm{HH}$ \\
\hline 7 & - & $t+$ & 世 & m & 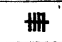 & + & H & - \\
\hline 8 & - & $\mathrm{HH}$ & $\mathrm{HH}$ & 册 & 曲 & H & $\mathrm{HH}$ & - \\
\hline 9 & - & + & $\mathrm{HH}$ & $\mathrm{HH}$ & $\mathrm{HH}$ & $t+$ & - & $+t$ \\
\hline 10 & - & - & - & - & + & W & $\mathrm{HH}$ & - \\
\hline 11 & - & - & + & tt & H & $\mathrm{HH}$ & $\mathrm{H}$ & $t+$ \\
\hline 12 & - & - & - & t+ & H & - & $\mathrm{HH}$ & + \\
\hline 健 康 海 猽 & - & t+ & $\mathrm{H}$ & WH & 世 & $\mathrm{HH}$ & $\mathrm{H}$ & $\mathrm{HH}$ \\
\hline
\end{tabular}

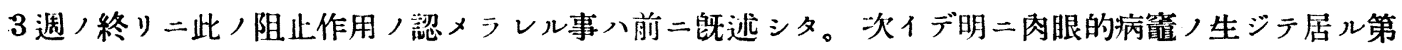

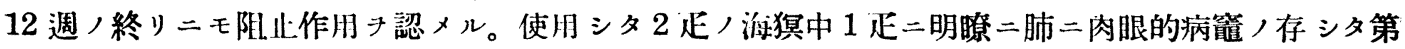
9 週二於テハ. 肺培地二モ阻山作用ガ見ラレタ。然シ乍ラ最初カラ第 12 週ノ終りマデ他ノ海猽二八 肺二病筑ナク又其ノ培地二モ阻止作用八認メ得ナカッタ。少 $1 / 10 \mathrm{mg}$ 接種時二比較シテ頻繁二時二八 比較的持綘的二留培地二絬核菌，阻止作月チ胃タノ八聊力異卜スルニ足ル事實デアラウ。

此, $1 / 1.000 \mathrm{mg}$ 接種淮猽于接種後 134 日目ニ「エーテル」デ殺シ剖見スルト淋巴腺ハ大小同異殆ンド 全テガ侵カサレテ居ルガ. 10 正中 4 辺八肝臟二於ケル病變が著明デ其ノ肥大八顯著デヌ極メテ固ク

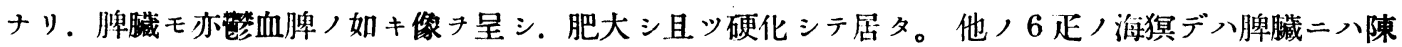

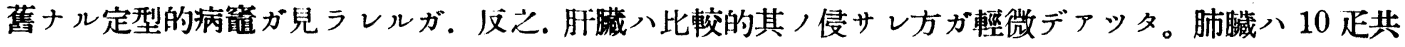

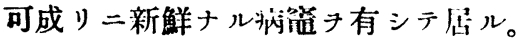

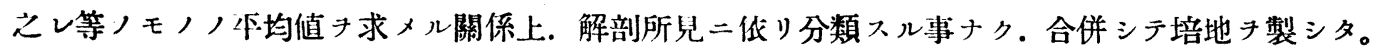
第 5 表 人型菌 $\mathrm{H}_{2} \quad{ }^{1 / 1} \cdot 1000 \mathrm{mg}$ 接種海冝(134 日) 贜器培地二於ヶル結核菌 $\left(\mathrm{H}_{2}, 37^{\circ} \mathrm{C} 30\right.$ 日培養 $)$

\begin{tabular}{|c|c|c|c|c|c|c|}
\hline . & $\begin{array}{l}\text { 繶地稀釋倍数 } \\
\text { 境 地 }\end{array}$ & $2 \times$ & $3 \times$ & $4 \times$ & $5 \times$ & $10 \times$ \\
\hline \multirow{2}{*}{ 胧 } & & + & $t+$ & t+ & $\mathrm{HH}$ & 册 \\
\hline & 健康海猽 胙 & + & $H$ & $\mathrm{HH}$ & $\mathrm{HI}$ & m \\
\hline \multirow{2}{*}{ 脾 } & & - & - & - & - & tt \\
\hline & 健凄海狙 脾 & + & $\mathrm{HI}$ & m & m & 册 \\
\hline \multirow{2}{*}{ 肺 } & & - & - & - & $+t$ & $\mathrm{H}$ \\
\hline & 健康海猽 肺 & $H$ & 曲 & HII & 册 & 册 \\
\hline \multirow{2}{*}{ 督 } & & - & - & + & t+ & $\mathrm{HI}$ \\
\hline & 健康海猽 䁂 & $\mathrm{H}$ & $\mathrm{m}$ & 册 & m & 册 \\
\hline
\end{tabular}

一發育セズ十聚落 1-2 個 + 聚落 10 個位 $\mathrm{H}$ 聚落多數 册 旺盛ナル發育 
培養所見八第 5 表二見ル如ク：肝培地二於テハ結核菌，發育八全然阴川:セラレズ搴ロ旺盛ナル發

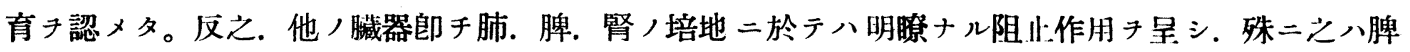
培地二著ルシク次イデ肺及ビ腎培地二モ此, 發育阻止作用八明二見ラレタノデァル。

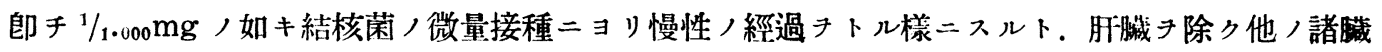
器二著明ナ阻止作用テ呈シ來ツテ. $1 / 10 \mathrm{mg}$ 接種二比シ發育阻止物質形成，上カラ見テ好條件ニアッ タト考へラレル。然シ售私，賽驗二ハ. 此, 阻止物質ガ如何ナル時期二產出サレ. 如何ナル時期二 消失スルカ，研究ガ缺ケテ居ルデ今後八允分此，問題ナ檢討スル積リデアル。

敦レニセヨKoch，基礎實驗キ成立サセルタメ，條件. 郎于初感染八微量ノ菌カラ始メテ成ル可

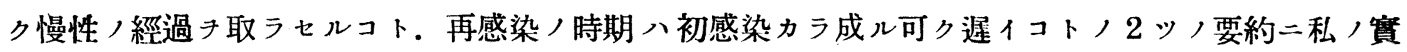
驗八丁度該當シテ居ル事ハ結核ノ免疫二於テ重大ナル示唆チ與へル點デハナカラウカ。

\section{BCG $\ni$ 海猽皮下二接種シタ場合}

上述シテ來タ人型菌ニ代フルニ $\mathrm{BCG}$ キ以テシタナラバ如们ナル結果二到達スル事ガ出來ルデア ラウカト思七. BCG Glycerinbouillon 加馬鈴著培地 3 週日培養 $0.2 \mathrm{mg}$ 于本等浮游液 (生理的食廐水)

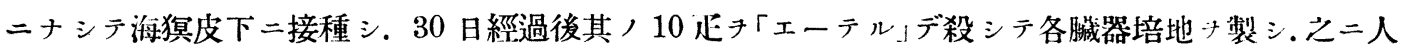
型結核菌 $\mathrm{H}_{2}$ Glycerinbouillon 3 週日培養, 濃厚本等浮游液チ移枯 シテ $37^{\circ} \mathrm{C}=30$ 日間放置シタ。

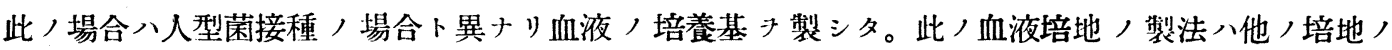
製法卜同樣二血液 1 二對 シ 蒸餾水 2 于加へ允分磨碎シテカラ $100^{\circ} \mathrm{C}=2$ 時間浸出 シ. 其，浸液二

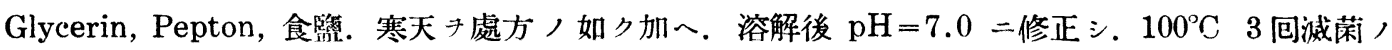
後二斜面トシテ使用シタノデァル。

第 6 表 BCG 0.2mg 皮下接種海猽(30日)贜器培地二於ヶル結核藏 (人型 $\mathrm{H}_{2}, 37^{\circ} \mathrm{C} 30$ 日培養)

\begin{tabular}{|c|c|c|c|c|c|c|c|c|}
\hline 臟 器 培 地 & \multicolumn{4}{|c|}{ 訮 } & 脾 & 兓 & 腎 & 血 \\
\hline $\begin{array}{l}\text { 海猽 } \\
\text { 接種日數 }\end{array}$ & $2 \times$ & $3 \times$ & $4 \times$ & $5 \times$ & $2 \times$ & $2 \times$ & $2 \times$ & $2 \times$ \\
\hline 30 日 & - & - & + & $t+$ & tt & Ht & tt & - \\
\hline 健 康 海 猽 & + & $t+$ & 世 & $\mathrm{H}$ & 世 & $\mathrm{H}$ & $\mathrm{HH}$ & $\mathrm{HH}$ \\
\hline
\end{tabular}

一發育セブ + 聚落 1-2 個 ++ 聚落 10 個位 $\mathrm{m}$ 聚落多數 $\mathrm{m}$ 旺盛ナル發育

其ノ培養成績カラ兒ルト．肝臟ト共二血液二明暸ナル發育阻止作用が認メラレタ。此，事實八或 八恐ラク人型結核菌 $\mathrm{H}_{2}$ キ接種シタ海猽ノ血液ニモ存フル事デアラウガ. 此, 瞔驗ハ人型菌 $\mathrm{H}_{2}$ 接種 ノ場合二八殘念二モ行ハナカッタカラ輕々二想像シ得ナ1。目下ハ此, BCG 接種ノ場合二血液中 二此，耐熱性結核菌發育阻止物質ガ產生セラレ且ツ其，消長二關シテ可成り興味津々タル成績テ反 復シタ實驗ニ於テ握ンデ居ルガ. 又稿ン改メテ報㝑ショウト思ツテ居ル。

孰レニセヨ. BCG テ海猽二接種スルト血中二阻止作用ガ顯現シ來ルハ事貫ナノデアル。從ツテ伊 藤氏 ${ }^{(5)}$ ) 行ツタ 實驗郎チ Wright ${ }^{(6)}$ ， slide cell culture デ最モ明暸二結核菌發有阻川:作用チ呈ス 
ルハ BCG 接種, 場合デァルト述ベテ居ル事カラ考へルト。私，物質，作用ト slide cell culture ，作用機轉トハー脈相通ズルモノガアルノデハナイカト思ハレル。極端ナル想像ガ諌サレルナラバ Wright ノ實驗卜私ノ經驗卜ハ同ジ原則ノ上二立ツトサへ云へルノデハナカラウカ。

\section{結核自然感染牛ノ肝贜培地}

上述，賽驗入全テ一定，條件下二行ッタ䁈驗的結核ノ場合デアル。然ラバ結核二自然感染シタ生 體ニアッテモ又此, 結核菌發有阻止作用八認メラレルノデハナイカト考へテ. 傳研二於テ比較的永

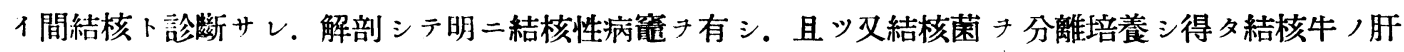

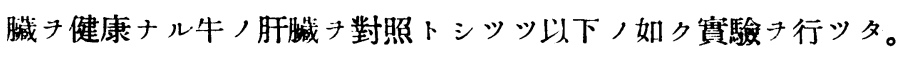

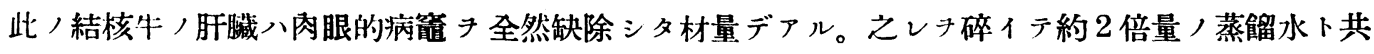
$=100^{\circ} \mathrm{C}=3$ 時間加熱浸出シ. 冷却後えレチ滤過スルト黃褐色，透明ナル滤液ガ得ラレル。此，濾

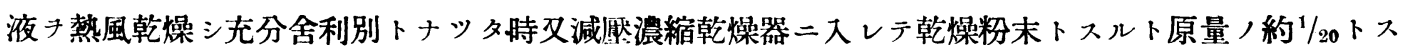
ル事が出來タ。從ツテ之ォ原量二復人ニハ $5 \%$ トレレバ良イワケデアル。

之ノ $5 \%$ 浸出液キ元トシテ Löwenstein 培地二擬へテ以下ノ如クニシテ其ノ培地テ製シタ。

\begin{tabular}{|c|c|}
\hline 第一燐酸加里 & $1 \mathrm{gr}$ \\
\hline 枸䋇酸: ソーダ、 & $1 \mathrm{gr}$ \\
\hline 硫酸 アグネシーム」 & $1 \mathrm{gr}$ \\
\hline 味之元 & $3 \mathrm{gr}$ \\
\hline 「グリセリン」 & $60 \mathrm{gr}$ \\
\hline 5 \%肝浸出液 & 1000 c.c. \\
\hline
\end{tabular}

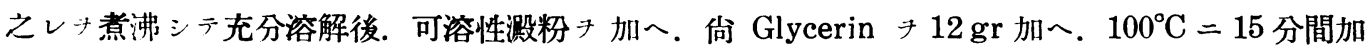

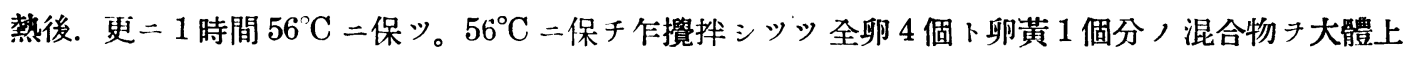

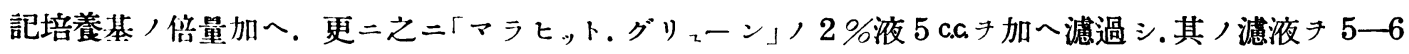
c.c.位宛試驗管二分注後. Tyndall，血清凝固器二入レ $80-85^{\circ} \mathrm{C}=3$ 日間隇菌・シテ杀斗面トナシタ。

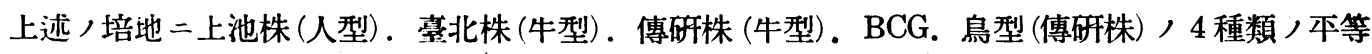
浮游液ノ濃厚ナルモ, 駒込「ピペ,ト」デ移植シタ。鳥型丹除ク他ハGlycerinbouillon 3 週日ノモ ノデァル。

其，培養成綨(第 7 表) ハ以下，如クデァル。

第 7 表 結核自然感染牛䏦培地二於ヶル結核菌ノ發育 $\left(37^{\circ} \mathrm{C} 21\right.$ 日培養)

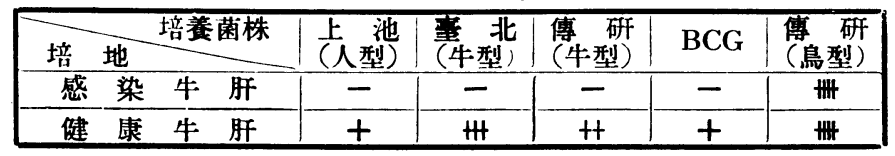

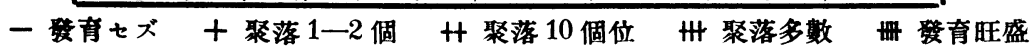


郎チ培地二移植シテカラ $37^{\circ} \mathrm{C}=21$ 日培養スルト. 上池株 (人型菌). 辜北株 (牛型). 傳研株 (牛 型). BCG 八自然結核感染牛肝培地二全ク發有シナイ二拘ラズ. 健康牛肝培地二八程度ノ差ハァレ 鬼二角發育八極メテ旺盛デァルノデァル。少鳥型菌二八何等ノ阻止作用ォ呈シテ居ナイ。

斯ノ如ク結核二自然感染シテ慢性ノ經過キトツタ牛, 肝臟二八朋暸ナル結核菌へノ發有阻忖作用 ガ認メラレタノデフル。

\section{結核菌墢育阻止物兵ノ作用檢討}

\section{非病原性抗酸性菌ノ發育习阻止スルカ}

大體既述シタ如ク結核菌へノ阻止作用ハ人型及ビ牛型へ，阻止.ノそデァッテ非病原性抗酸菌二八 作用シナイノデハナカラウカトハ. 自然感染牛, 肝培地二於ケル培荃成績カラ推察シ得ル所デアル ガ. 更二入念二之チ檢討スル事トシタ。

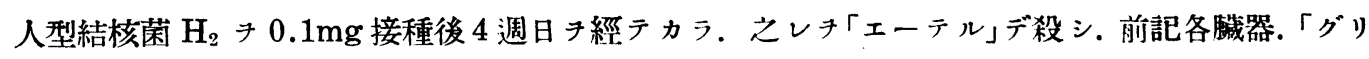

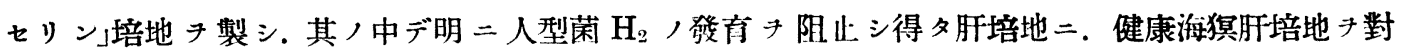
照トシテ. 傳研「ッベルクリン」室カラ分與チ受ケタ非病原性抗酸性菌 $\mathrm{A}_{4}, \mathrm{E}_{\overline{7}}, \mathrm{E}_{3}, \mathrm{C}_{16}, \mathrm{~B}_{5} ， 5$ 菌株 (Glycerinbouillon 1 週日培養)二就テ各々，濃厚本等浮游液ン移植 $337^{\circ} \mathrm{C}=$ 放置シタ。斯クスル ト48時間目二八各菌株共極メテ明暸旺盛ナル發育チ示シ聊カノ發育阻止ノ片鱗キダ二認メ得ナカッ タ。郎于人型菌及ビ牛型菌へノ發育阻止チ來入物質八非病原性抗酸性菌ニハ何等ノ影㹕キ與へナ1 事が知ラレル。從ツテ此ノ場合人型菌及ビ牛型菌へ, 發育阻止物質,特異性キ云々シタイガ. 逆, 實驗郎于此レ等, 非病原性抗酸性菌, 接種二依り海猽體內二人型及ビ牛型菌へ，發育阻止物質力゙産 生サレナイト,反證ガ擧ゲラレテ居ナイカラ特異性カ否カノ結論ハ下シ得ナイ。

\section{人型菌 $\mathrm{H}_{2}$ 株二淢殺的二作用スルカ}

上記，人型菌 $\mathrm{H}_{2}$ 接種海猽，肝臟浸出液 4.5c. $a=$ Glycerin-bouillon $=3$ 週間培養シタ中試驗管

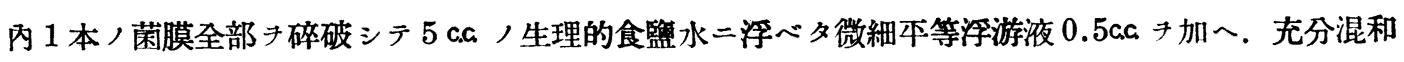
シテカラ $37^{\circ} \mathrm{C}$ 二放置シ. 每日 8 日間二瓦り其ノ數滴キ熊谷培地二培養シテ殺菌サレタカ否カォ 3 週 間培養二依リ檢シタガ. 結核海猽肝浸出液卜菌卜ノ接觸 8 日二至ルモ何等殺菌サレル事ナク旺盛二 熊谷培地二發育シタ。

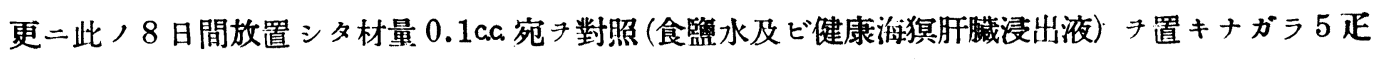

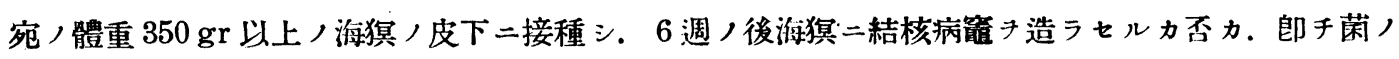
毒力 (Vilurenz) 二變化ハナイカト思ヒ. 之レチ殺シテ剖胃シタガ對照二比シ其ノ毒力キ低下シナイ コトキ知ツタノデアル。

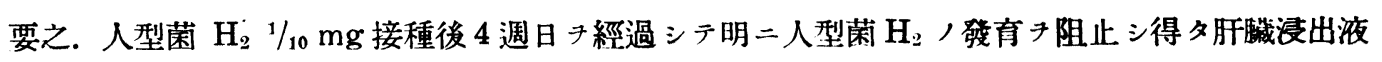
八人型菌 $\mathrm{H}_{2}$ チ殺菌スル能力ハナク. 又菌ノ毒力チ变失セシメナィ。更二非病原性抗酸性菌, 發 
育ニ八影䍹ナ與へズ. 飽ク迄人型菌及ビ牛型菌へノ發育阻止ガ其ノ作用ノ本態デアル如ク思ハレ u。

\section{考察竝二結論}

上迅ノ如クシテ私八䊅核罹患海犋體內二結核菌發育阻止物質，產生セラレルラシイ事及ビ其／消 長二就テ城告シタ。斯ノ如キ耐熱性ノ發育阻止物質ナルモノ八一體結核免疫二於テ如何程ノ意義き 有フルカチ少シ考察シテ見タイ。

緒言二モ述べタ通り．結核菌ハ「キチン」質．蜢及ビ脂肪等カラナル被膜ニ被ハレ．其ノ內部二生 活力アル原形質丹藏入ル關係上. 之ガ侵入ォ蒙ツタ生體細胞モ之二對抗シ之キ克服入ル二八並々ナ ラヌ障碍二逢著入ル結果トナリ。他ノ急性傳染病二見ラレル樣二．抗毒素或七ハ溶菌素等ノ明暸二 效果アル抗體キ豐富二迅速二產生スル場合卜結核, 免疫キ同一二論ズ可ラザルハ言キ俟タヌ所デァ ラウ。此ノ樣ナ觀點二立脚シテ始メテ．從來成サレテ來タ夥シイ此ノ分野二於ケル研究業績モ批制 シ且ツ把握シ得ルノデハナイカト考へラレル。

此, 結核菌被膜, 重要性、Anderson (7) カ菌體力ラ得タ所謂 Lipoid 中ノ成分・殊二Aceton 不 溶. Alkohol-Äther 可溶, 分劃部分.(Phosphatid A-3) ガ Sabin, Doan 及ビ Forkner ${ }^{8}$ (9)等/詳細 ナル研究ニヨリ。之レ等ノ刺戟二依ツテ動物體内二結核, 族理二於テ決定的ナル要素デアル上皮樣 細胞. 上皮樣巨大細胞及ビ絬核縕織形成セシムルトノ報告ニヨッテモ知り得ル所デァル。

此ノ被膜ガアッテ結核菌ハ外部侵襲カラ保護サレテ居ルタメ．試驗管內八㓜論ノ事生體內二於テ

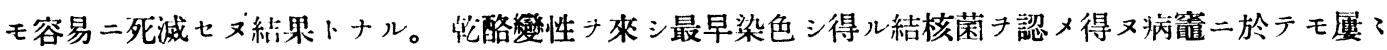

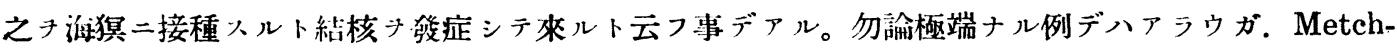

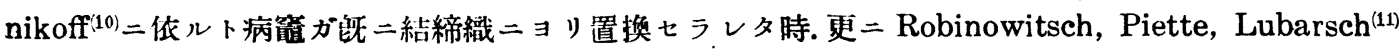

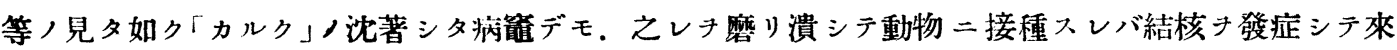
ルトノ事デアル。

要之: 私八結核菌ハ其，菌體ノ特有ナル構造上生體內ニアッテ容易二死隇セヌト云フ事テ特二此 處二强調シタイノデァル。既二古ク碩學 Robert $\operatorname{Koch}^{(12)}$ 八結核ノ治療劑ノ檢索二際シ。一部世人

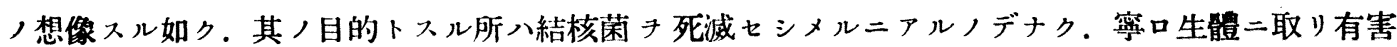
デアル菌ノ發有又ハ增殖丹阻止入レバ足リルト喝破シテ居ルノ八蓋シ至言デアラウ。

結核菌二對シ感受性,無勳物ハ天然二結核菌二對スル莬疫ガ賦與サレテ居リ．接種サレタ結核 菌ハ，直チ二殺サレル事ナク．無害ノ異物レシテ生體內二滯留スル二過ギナイ。之ノ際別二生體細 胞卜菌トノ間二共生が營マレテ居ナイ事ハMetchnikoff ${ }^{(13)}$, Dembinski ${ }^{(14)}$, 弘重氏 ${ }^{(15)(19)}$. 渡㟟氏 ${ }^{(17)}$ 等 ノ研究カラ容易二推察シ得ル所デアル。

結核菌二對シ感受性アル動物ガ再感染時二示ス抵抗ノ問題. 郎チ吾人二取り最モ重要ナル啳天免 疫ハ 1891 年 Koch ${ }^{(1)}$ 二依り實驗的根據テ與へラレテ以來. Della Cella ${ }^{(18)}$, Feistmantel $^{(19)}$ 及ビ Kraus 
及ビ $\mathrm{Grosz}^{(20)}$ チ經テ Römer ${ }^{(21)}$, Hamburger ${ }^{(22)}$ 二依リ其ノ事貫デアル事が確認セラレルニ至ッタ。 然シ相當後マデ此ノ所謂 Koch ノ基礎實驗トシテ後世世人二喧傳七ラレ. 實二結核ノ免度キ說明ス

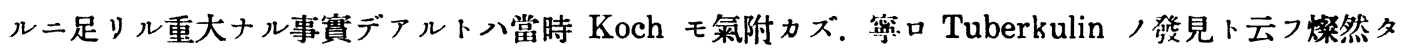

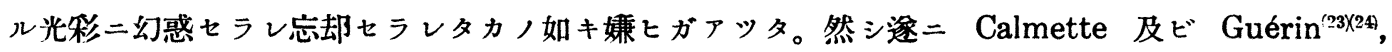
Römer 及ビ Joseph ${ }^{(25)}$, Finzi ${ }^{(26)}$, Bezançon 及ビ Serbonnes ${ }^{(27)}$, Schieck ${ }^{(28)}$ 等，出ズル二及ビ俄二 Koch 基礎實驗八其本來ノ生彩き取り㞍シ今日ニ至ルマデ結核免疫ノ理論的根據卜シテノ名馨キ保 持シテ居ルノデアル。

Krause 及ビ Willis ${ }^{(29)}$ 二依ルト再感染時二接種サレタ絬核菌八. 促進性炎症二起因シテ其；侵入 局所二固定サレルノデァルト說明シテ居ル。中谷氏 ${ }^{(30)}$ 二低ルト結核菌ノ體內播布逮延現象八細胞反

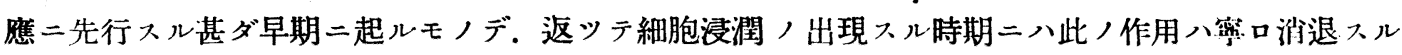
ト述べテ居ル。

以上ノ如ク Allergie ガ結核免疫ト不郎不離ノ關係ニアルトシ中ニハAllergie 郎于免疫デァルト 極論スル人々スラアル。

Römer 及ビ Joseph ${ }^{(25)}$, Hamburger ${ }^{(31)}$, Neufeld ${ }^{(32)}$, 佐多氏 ${ }^{633)}$. Willis ${ }^{(34)}$, 南氏 (35/7) $_{(35)}^{(366)}$ Löwenstein ${ }^{(38)}$,

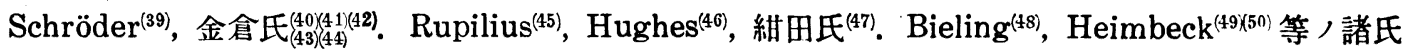
ハ之レニ屬スル。

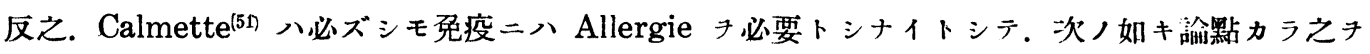
有力二反駁シテ居ル。郎于結核二對シ天然免疫ノアル生體ハ强毒, 結核菌チ接種シテモ Allergie トハナラナイ。多クノ賽驗者ノ報告ニヨルト感受性アル生體ト雖モ常二必ズシモ Allergie キ有セ ナケレバ再感染二抵抗シナイト云フ事ハナイ。紫外線ノ如キ facteurs anergisants 八 Allergie キ阻ゲルガ. 免疫ニハ影響キ與へナイ。Tuberkulinキ最初微量カラ接種シ次第二增量シテ之二慣入 ト Allergie ハ消失スルガ其，再感染へ，抵抗亣減弱シナイ。南河デ Transwaal /鐄山二於テ黑人 工夫ノ探用時二 Tuberkulin 反應子試えルト其ノ陽性率八甚ダ高イガ後ノ絬核發症キ阻ゲル何等, カトナラナイトノ S. Lyle Cummis ノ報告等キ取り擧ゲテ居ルノデァル。

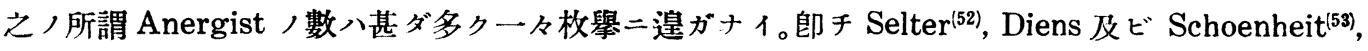
Pirquet ${ }^{(54)}$, Dold ${ }^{(55)}$, 貴島氏 ${ }_{(59) ;(60)}^{(56)(58)}$. Branch 及ビ Cuff ${ }^{(61)}$, van Beneden ${ }^{(62)}$, Klopstock ${ }^{(63)}$, Clawson ${ }^{(64)}$, H. Koch 及ビ Brudnicki ${ }^{(65)}$, Boquet 及ビ Brettey ${ }^{(66)}$, Nasta ${ }^{(67)}$, 箭頭氏 ${ }^{(68)}$. 戶田及ビ箭頭氏 ${ }^{(69)}$. Thomsen 及ビ Pedersen Bjergaard ${ }^{(70)}$, Klopstock, Pagel 及ビ Guggenheim ${ }^{(71)}$, 戸田氏 ${ }^{(72)(73)}$. 川

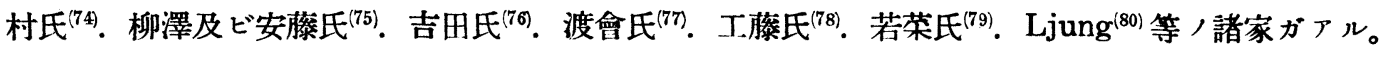

要之. Koch ノ基礎實驗き說明スル二足ル事實トシテ Allergie ノシデハ无分デナク．賽驗的二ハ 一定條件下二ハAllergie ノナイ免疫或ハ免疫,無1 Allergie ガ存シ得ルト云フ點キ强調シタノデ アッテ. Allergie 八兌疫二於テ相當ノ意菚ガァルトシテモ. Allergie 即チ免疫ト八全ク云ヒ切レナ イト云フ事キ示スモノデアラウ。 
Selter ${ }^{(81)}$ 二依ルトKoch /基礎實驗ハ可ナリ皮膚組織/過敏性變調二倚存入ルモノデアッテ殊二 海猽ニアッテハ結核ガ相常進ンデカラ出現スルモノデァルコトハ認メル。然乍ラ此, Allergie ハ結 核菌, 身體內部人, 侵入丹阻止スルカデハナ1。故二此, 事八再感染菌, 侵襲防禦二於テハ唯下次 ニ位スルモノデアッテ.此ノ防禦八唯々生體ノ內部力(酵素ノ如キモノ) ニョッテノミ果サレルノデ. アルト考へテ居ル。

最近小林六造氏 ${ }^{(82)}$ ハ「ゲルトネル」及ビ豚「コレラ」等ノ動物賽驗カラ類推 シテ結核免疫ノ場合タ次 ノ如ク述ベテ居ル。增殖炎性疾病二於テハ始メテ侵入シタ原因菌, 增殖二低ツテ身體が一定, 變化 チ受ケテァル性能カ賦與サレル。其，性能ハ一定時間後二同一病原菌，再侵入又八體内二於テ分裂

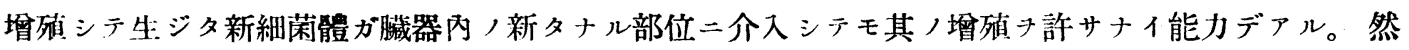
シ之キ殺隇ショウトシナイモノデアル。斯樣ナ現象象疫現象人一種デアルト考へル事ガ出來ルト。

Selter, 所謂生體內部,力. 小林教授, 見解郎于體內二於テ原因菌/增殖キ許サナイ能力ト云フ 如キ點力ラ考へテ私ノ云フ本物質(耐熱性結核菌發有阻止） チ以ッテ結核免疫ノ全テチ說明シ得ナ イニシテモ可成り/重要ナル部分キ說明シ得ルノデハナカラウカト考へラレル。

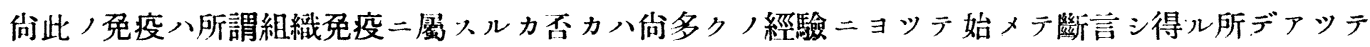
此處ニニワカ二決論シ得ナ1。倘私ハ BCG 接種海猽二於テ其ノ血液培地が明暸二結核菌ノ發育き

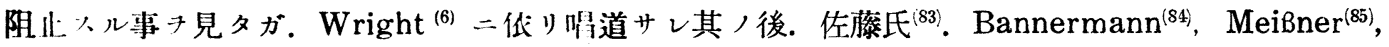

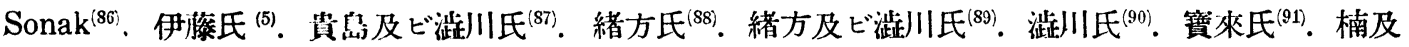

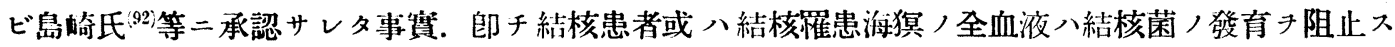

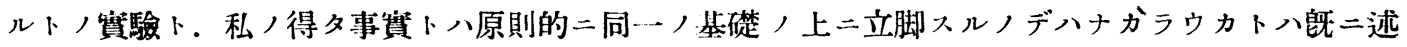
ベタ所デアル。而シテ此ノ作用タ呈入ル物質ハ元來組織内二產生サレタモノガ. 必要二應ジテ血流

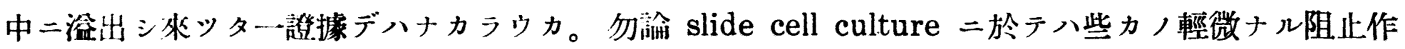
用モ其ノ手技上カラ罗テ當然出現入可キ場合二。私ノ方法デ八餘程强度二其ノ作用ガ發揮サレナィ 限り阻怍用于呈シナイト云フ位ノ差ハアルデアラウ。

以上ノ記述二低り私ハ自分ノ云ハントシタ事ハ漏レナク吐露シタ積リデアッテ. 是以上述べル事 八聊力蛇足二類スル嫌ハアルケレドモ。少クトモ今回，賽驗ノ契機トナッタ二三ノ文獻テ此處二紹 介スルセ徒爾デハアルマイ。

Fontes $^{(93)}$ (1909 年) 八結核感染海猽, 淋巴腺中二八試驗管內デ結核菌ノ數キ減少セシメル能力アル 物質，存スル事き見テ居ル。Livierato ${ }^{(94)}(1910$ 年) 八淋巴腺 (結核海猽ノ) ) 無菌的滤液チ以テ前處置 スルト。之レ二結核菌チ感染セシメテモ海猽二於ケル結核性病變ハ輕微デアッタト云フ事デアル。

Webb, Ryder 及ビ Gilbert ${ }^{(95)}$, Corper, Lurie 及ビ Kretschmer ${ }^{(96)}$, Webb, Poissevain 及ビ Ryder $^{(97)}$ 等二依レバ結核海猽，淋巴腺ハ $38^{\circ} \mathrm{C}=15$ 日間隇菌生理的食監水中二放置スレバ其ノ中二 アル結核菌ハ其ノ毒力キ失うト云フ事デァル。更二 de Potter ${ }^{(98)}$ ハ之レチ追試シ同樣ノ所見チ得タ ガ. 之八材量キ其, 儘海猽, 皮下二接種シテモ. 何等, 㻐症八見ラレナイガ. 反之. 此ノ結核淋巴 


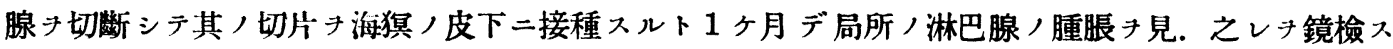
ルト多數ノ結核菌が證明出來タ。然ルニ豐田氏 ${ }^{(99)}$. 田結 ${ }^{(100)}$ 等ニヨルト之レ等諸氏八見解ト八異ナリ 恰モ Typhus 菌. Cholera 菌等ニ見ル如キ結核菌八動物ノ淋巴腺通過ニョリ其ノ毒力ォ增シ且ツ溶

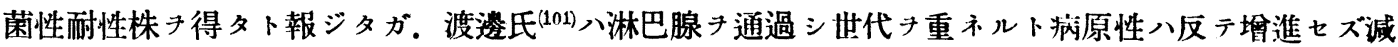

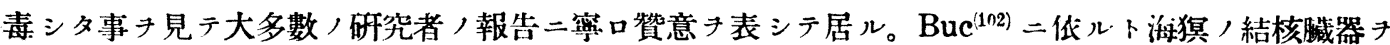
取》 $37^{\circ} \mathrm{C}=$ 放置スルト各臟器中，結核菌ハ，肝臟デハ $3-6$ 日。脾㖑デハ $10-14$ 日，淋巴腺デ八 8-11 日デ. 其ノ毒力八消失スルト云フ事デァル。

上述，諸研究八直接私，得タ物質二八關係ハナイカモ知レヌガ. 生體，結核菌二對入ル防橴機轉 ノ上カラ何物シカ暗示スルノデハナカラウカ。

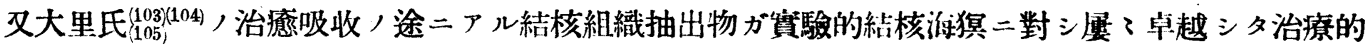
作用アリト，報告モ私，研究二對シ示唆き與へタ事ハ多大ナルモ，ガアル。更二佐々木及ビ梅田 氏 ${ }^{(106)}$ 二依ル結核組織ガ特異ナル抗元性キ有スト，研究モ同樣興味チソソル二火第デアル。

私，賔驗範圍二於テハ決論卜シテ下，如キ事ガ云へルト思つ。

1. 實驗二於テ示入如ク耐熱性絬核菌弡育阻止物質ガ結核羅患漼猽體內二產生セラレルラシイコ トキ證明シ得タ。

2. 此ノ證明法トシテ, 賽驗方法キモ述べタ。

3. 或ル程度, 發育阻止作用八健康動物，各㖑器二モ你入ルガ. Tuberkulin 反應カ陰性カラ陽

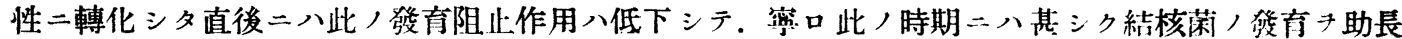
セシムル(此ノ事八第二報二詳述スル)。

4. 人型結核菌 $\mathrm{H}_{2}$ 株 (强毒菌) $1 / 10 \mathrm{mg}$ 于海猽皮下二接種シタ場合二八. 肺及ビ脾二肉眼的病䈱

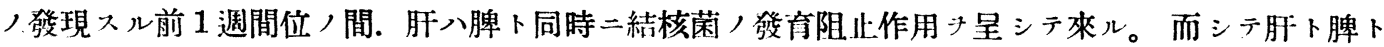
ノ此ノ作用ハ病變が相當進行シテ肉眼的病䇴, 明二生ジタ時期二於テモ時々見ラレル。而シテ感染

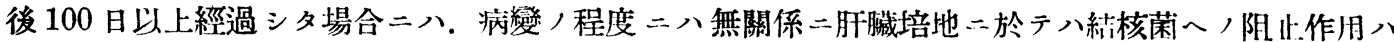
失ハレル。脾及ビ腎, 培地ニモ同樣結核菌, 矩育八旺盛デアル。反之. 比較的新鮮ナル病篰キ多ク 有スル肺二於テハ明暸ナル結核菌ノ發育阻止作用习認メタ。

5. 人型結核菌 $\mathrm{H}_{2} \neq 1 / 1.000 \mathrm{mg}$ 海猽皮下二接種シタ場合二八. 脾二於テハ先ヅ其，肉眼的病渻， 發現一步手前ノ時期二結核菌ノ發育が阻止サレタ。少腎裁二モ時々此ノ阻止作用が見受ケラレタ。而 シテ此,阻止作用ガ肝臟二出現シテクルノハ。 $1 / 10 \mathrm{mg}$ 接種ノ場合ト異ナリ感染早期デハナク. 第 10 週ノ終リデアリ．且ツ觀察ノ末期郎チ第 $11-12$ 週ノ終りマデ此，作用八續キ。 $1 / 10 \mathrm{mg}$ 接種時／如ク

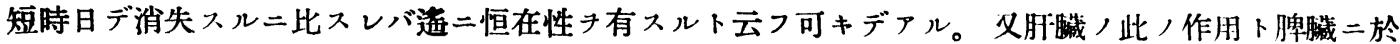
ケル夫レハ $1 / 10 \mathrm{mg}$ 接種時, 如ク同時二相伴フ所見ハ見ラレナカッタ。

次二1/1.000 mg 接種後 134 日ナ經タモノデ 10 正二就テ檢スルト肝臟二八結核菌阻止作用八全然認 メ難イガ. 反之. 脾. 肺. 腎二於ケル阻止八著明デ. 殊二脾二於テハ極メテ明暸二且高度二阻止作 
用チ兒タ。少肺及ビ腎二於ヶル作用モ亦著明デァル。

此, 事八Koch，基礁實驗丹成立七シメルタメ，條件. 郎于初感染，菌量八微量デ海猽二慢性， 經過斗取ラセル事。及ビ再感染，時期八初感染カラ崌イ程良好デアル事。ト，要約二 $\mathrm{H}_{2} 1 / 1$.000 $\mathrm{mg}$ 接種が丁度該裳シタモノデァラウト考へラレル。

6. BCG $0.2 \mathrm{mg}$ キ派猽皮下二接種シ 30 日後ニソノ䏼器培養所見キ兒ルト肝贜及ビ血液二明暸ナ 几阻止作用ガ看取出來タ。

7. 人型結核菌 $\mathrm{H}_{2} 1 / 10 \mathrm{mg}$ 接種淮猽二於テ 4 週日チ經タ明暸二人型菌 $\mathrm{H}_{2}$ 人弡育丹阻止七儿朋臟 浸出液ハ 5 種類, 非病原性抗酸性菌, 發育ナ阻止セズ. 8 日間 $37^{\circ} \mathrm{C}$ 二放置シタノデハ人型菌 $\mathrm{H}_{2}$

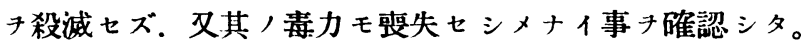

8. 結核二自然感染シタ牛二於于. 其, 肝臟八人型菌 (上池株). 牛型菌 (臺北株. 傳研株). BCG 人發育于明暸二阻止シタ。

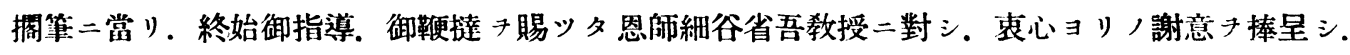

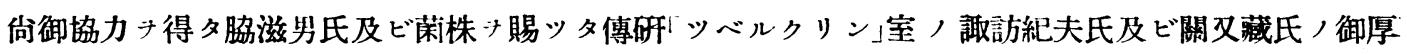
情二對シ感謝スル次第デアル。

\section{文㗔}

1) Koch, R., D. m. W., 17, 101, 1891.

2) 日圈達男, 結核. 14, 734. 昭和 11.

3) Courmont P. et Gardère, H., C. R. Biol., 95, 837, 1926.

4) 米田庄三郎, 結核. 15, 162. 昭和 12 .

5) 伊藤種次郎, 結核. 8, 291. 昭和 5.

6) Wright, A. E., Lancet, 1, 218, 1924.

7) Anderson, S. J., J. biol. chem.. 74, 537, 1927.

8) Sabin, F. R., Doan, C. A. and Forkner, C. E., J. exp. med. Suppl. No. 3, 52, 1, 1930.

9) Sabin F. R., Doan, C. A. and Forkner, C. E., ibid., Suppl. No. 3, 52, 73, 1930.

10) Metchnikoff., Calmette's „Tuberculose “, (1936). 238 頁引用.

11) Rabinowitsch, Piette, Lubarsch., 同上. 239 頁引用.

12) Koch, R., Schwalbe's Gesammelte Werke von Robert Koch, I, 650, 1912.

13) Metchnikoff., Virchow's Archir, CXIII, 63, 1888.

14) Dembinski, M., Ann. Instit. Pasteur, XIII. 426, 1899.

15) 弘重壽輔, 結核. I, 39. 大正 12 .

16）弘重韾輔. 結核. I, 564. 大正 12 .

17）渡邀義政，結核/細菌學及免度學. 細菌學雜誌棌. 東京. 108. 昭和 15.

18) Della Cella, F. A., Centbl. f. Bakt., Orig., 36, 12, 1904.

19) Feistmantel, Centbl. f. Bakt., Orig. 36, 282, 406, 1904.

20) Kraus, R. und Grosz, S., ibid XLVII, 298, 1908.

21) Römer., Calmette's „, Tuberculose “., 741 頁引用.

22) Hamburger, F., Beitr. z. Kl. d. Tbk., 12, 259. 1909. 
23) Calmette, A. et Guérin, C., Ann. Instit. Pasteur, 21, 525, 1907.

24) Calmett, A. et Guérin, C., ibid. 22, 689, 1908.

25) Römer u. Joseph., Beitr. z. Klin. d. Tbk., 13, 1, 1909; 17, 287, 345, 357, 365, 427, 1910.

26) Finzi, G., Rec. de méd. vétér., 88, 102, 1911.

27) Bezançon et de Serbonnes., Ann. de mèd., 1, 129, 1914.

28) Schieck, F., Veröffentl. d. Robert Koch Stiftung, 1913.

29) Krause, A. K. und Willis, H. S., Amer. Rev. Tbc., 14, 316, 1926.

30）中谷繁一, 結核. 13, 642, 昭和 10.

31) Hamburger, F., Wien Klin. W., XXI, 1043, 1908.

32) Neufeld, F., Z. f. Tbk., 34, 312, 1921.

33）佐多愛彥, 結核. I, 14. 大正 12 .

34) Willis, H. S., Amer. Rev. Tbc., 11, 439, 1925.

35）南廣憲, 結核. 3, 867, 大正 14.

36）南廣憲, 結核. 3, 905. 大正 14.

37）南廣憲, 結核. 3, 929. 大正 14.

38) Löwenstein, E., Wien. klin. W., 41, 653, 1928.

39) Schröder, G., Lancet, 1, 167. 1927.

40）金倉和三郎, 結核. 8, 861. 昭和 5.

41）金倉和三郎, 結核. 8, 1037. 昭和 5.

42）金倉和三郎，結核. 8, 1072. 昭和 5.

43）金倉和三郎，結核. 8, 1106. 昭和 5.

44）金倉和三郎, 結核. 9, 408. 昭和 6.

45) Rupilius, K., Wien klin. W., 45, 1412, 1932.

46) Hughes, J., J. immun, XXV, 103, 1933.

47）紺田孫助, 十全會雜誌. 39, 178. 昭和 9.

48) Bieling, R. und Oelrichs, L., Beitr. z. Klin. d. Tbk., 9, 491, 1937.

49) Heimbeck, J., Med. Klin., 29, 1731, 1933.

50) Heimbeck, J., Centbl. f. Tbk. forsch., 45, 537, 1937.

51) Calmette, A.. Ann. Instit. Pasteur, XLIX, 279, 1932.

52) Selter, H., D. m. W., 51, 933, 1925.

53) Diens, L. und Schoenheit, E. W., Amer. Rev. Tbc., 13, 379, 1926.

54) Pirquet, C., Wien. . klin. W., 41, 797, 1928.

55) Dold, H., D. m. W., 53, 12, 1927.

56）貴島定和，結核. 8, 932，昭和 5 .

57）貴島定和，結核. 8, 1399. 昭和 5 .

58）貴島定和，結核. 8, 1411. 昭和 5 .

59）貴島定和，結核. 8. 1450. 昭和 5 .

60）貴島定和，結核. 8, 1459，昭和 5 .

61) Branch, A. and Cuff. J. R., J. infet. dis., XLVII, 151, 1930.

62) van Beneden. J., C. R. Biol., 109, 50, 1932.

63) Klopstock, F., Z. f. Tbk., 65, 275, 1932.

64) Clawson, B. J., Proc. Soc. Exp. Biol. and. Med., 31, 105, 1933. 
65) Koch, H, und Brudnicki, E., Med. Klin., 29, 1280, 1933.

66) Boquet A. et Brettey, J., C. R. Biol., 113, 807, 1933.

67) Nasta, M., C. R. Biol., 113, 495, 1933.

68）箭頭正男，滿洲緊學會雜誌. 18, 519. 昭和 8.

69) 戶田忠雄, 简頭正男, 結核. 11, 806. 昭和 8.

70) Thomsen, O. und Pedersen-Bjergaard, K., Acta Path. et Microbiol. Scandin. Suppl., 16, 521, 1933.

71) Klopstock, A., Pagel, W. und Guggenheim, A., Klin. W , 11, 1826, 1932.

72）戸田忠雄，東京䃜事新誌. 2887 號. 1685. 昭和 9.

73） 戶田忠雄, 賽地竪家卜臨林. 13, 626, 昭和 11.

74）川村一男, 結核. 15, 1100. 昭和 12.

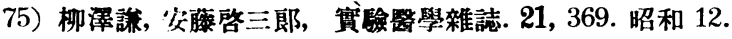

76）吉田長之, 東京瞕求新誌. 3097 號. 2215. 昭和 13.

77）渡會浩, 結核. 16, 1167. 昭和 13.

78）工藤友太郎，結核. 16，1498。昭和 13；16，1545。昭和 13.

79）若荣秋：，結核. 17, 107. 昭和 14.

80) Ljung, O., Z. f. Tbk., 83, 1, 1939.

81) Selter, H., Z. f. Thk., 67, 1933.

82）小林六造, 日本醫學及健康保險. 3218 號. 239. 昭和 16.

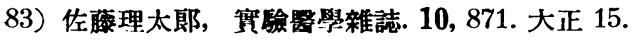

84) Bannerman, R. G., Brit. J. Exp. Pathol., 8, 209, 1927.

85) Meißner, G., Zentbl. . f. Bakt., Orig., 106, 210, 1928.

86) Sonak, M., Zentbl. f. Bakt. Orig., 115, 173, 1930.

87）貴島定和, 啮川隆曹, 結核. 8, 1450. 昭和 5.

88）緒方準一，結核. 10, 117. 昭和 7.

89）緒方準一. 龁川隆曹，結核. 10, 247. 昭和 7.

90）啮川隆曹, 結核. 11, 63. 昭和 8.

91) 筫來着次, 結核. 14, 370. 昭和 11.

92）楠節子, 鳥崎節, 結核. 14, 456. 昭和 11.

93) Fontes, A., Zentbl. f. Bakt. Orig., 50, 78, 1909.

94) Livierato, S., Zentbl. f. Bakt. Orig., 54, 332, 1910.

95) Webb, G. B., Ryder C. T., , and Gilbert, G. B. Amer. Rev. Tbc., 5, 388, 1921.

96) Corper, Lurie and Kretschmer., Amer. Rev. Hyg., 1929.

97) Webb, G. B. Poissevain C. H. und Ryder, C. T., Amer. Rev. Tbc., 9, 534, 1924.

98) de Potter. F., C. R. Biol., 92, 1346, 1925.

99）豐田秀造, 楊永年, 細菌學雜誌. 339 號. 981. 大正 13.

100）田結宗誠, 結核. 2, 113. 大正 14.

101）渡邉義政，結核／細菌學及免投學. 細菌學雜誌社. 東京. 148 頁. 昭和 15.

102) Buc, E., C. R. Biol., 109, 433, 1932.

103）大里俊吾，結核. 12,324 . 昭和 9 .

104) 大里俊吾, 結核. 15, 634. 昭和 12.

105）大里俊吾, 芦洣藤亮, 結核. 15,635 . 昭和 12 .

106）佐 々木源三郎, 梅田芳次郎, 北海道噌學雜誌. 18, 1954. 昭和 15.

（屡：引用七シ Calmette's „Tuberculose “ $ト$, Boquet et Négre, L',infection bacillaire et la tuberculose chez l'homme et chez les animaux, Masson et Cie Editeurs, Paris, 1936 人略ナリ) 